\title{
Assess the knowledge, practice and attitude of pregnant women for effect, of calcium during pregnancy
}

\author{
Tahany Sh. goda ${ }^{(1)}$ Nadia M. Fahmy ${ }^{(2)}$ Soad A.S.Ramadan ${ }^{(3)}$ HematM.ELbana $^{(4)}$ \\ (1) Clinical Instructor in school nursing- ALkanater EL khairia \\ (2) Maternal and Newborn Health Nursing Faculty of Nursing Ain shams University \\ (3) Maternal and Newborn Health Nursing Faculty of Nursing Benha University \\ (4) Obstetrics and Women's Health Nursing Faculty of Nursing Benha University
}

\begin{abstract}
Background: Maternal calcium absorption increases significantly during the second and third trimesters. This increase in calcium absorption is directly related to maternal calcium intake if found defect in calcium level during pregnancy that causes many problem for mother and fetal. This study Aimed to: assess the knowledge, practice and attitude of pregnant women for effect, of calcium during pregnancy. According to (W.H.O, 2014) the prevalence of hypocalcaemia 50\% from women that exposure to osteoporosis. Every four women found one man exposure to osteoporosis. Subjects and Methods: A descriptive design study conducted at both in outpatient clinic for pregnant women, in obstetrics and gynecology department at Benha university hospital. The study included 300 pregnant women by systematic random sample. Tools: (I) An interviewing questionnaire sheet was selected constructed by researcher, tool (II) Modified liker scale to assess women attitude Result: highly statistical significant relation between their knowledge and their personal characteristics. No statistical significant relation between their total practice score and their personal characteristics. No statistical significant relation between his attitude and their occupational status, educational level and social level. Conclusion: low level of knowledge about the important of calcium for fetus, Poor practice toward calcium intake, the calcium supplementation Recommendations: Health educational, Programs regarding nutritional, in the future calcium supplements should be give free.
\end{abstract}

Key words: Pregnancy, Calcium, Knowledge, Practice, Attitude.

Introduction

Calcium has play a major role in transmission of nerve impulses. It helps regulate muscle contraction and relaxation, including normal heart beat. Calcium has a vital role in the cardiac action potential and is essential for cardiac pacemaker automaticity (Nix et al., 2014)

Calcium may interfere with the absorption of iron from supplements or diet.
Although the mechanism by which calcium inhibits intestinal absorption of iron remains unclear, interference begins, is approximately $300 \mathrm{mg}$ of calcium. Most calcium supplements contain significantly more than this amount. If the pregnant are taking iron and calcium supplements in the same time that leading to reduce the effect of iron supplement and potential interactions with foods. (Woodrow et al., 2011). 
Calcium homeostasis in pregnancy is slightly different from that of non-pregnant state to meet the calcium demands of the mother and fetus. Total calcium level is decreased during pregnancy due to hemodilution associated low albumin. Calcium during lactation the mother undergoes a continued stress on calcium demand with production of breast milk. On an average $300-400 \mathrm{mg}$ of calcium is lost by breast milk daily. (Kovacs et al., 2013).

The need for calcium required during pregnancy approximately $1000 \mathrm{mg} /$ day and in the post-partum period for fetal skeletal mineralization, secretion of breast milk, and growth during infancy. The calcium for skeletal mineralization is supplied by the mother across the placenta during fetal life and through breast milk during infancy. At birth, an infant's body contains 20-30 g Ca, almost all of which is in the skeleton (Pettifor.,2010). .

Hypercalcemia may occur from excessive intake of calcium or increase dose of calcium supplementation or other factor such as Primary hyperparathyroidism and malignancy account for more than $90 \%$ of the case of hypercalcemia in ambulatory and noncritical ill women. Only a small percentage of hypercalcemia cases are due to immobilization, vitamin $\mathrm{A}$ and $\mathrm{D}$ intoxication, lithium use, and thiazide diuretics. (Gardner et al.2012

Hypocalcaemia for pregnant women result from increase calcium absorption, and if she does not consume adequate amounts of dietary calcium, she may be at increased risk for gestational complications, such as preeclampsia, and preterm delivery or longterm morbidities, such as excessive bone loss. Fetal with hypo calcimia neonatal rickets and tetany, and infantile rickets during infancy has been associated with higher prevalence of lower respiratory tract infections (Villar et al.,2014)
The role of nurse it's very important to prevent problem during pregnancy by explain to the women and family the changes that occur in calcium level during this period, how to prevented by give health education about source of calcium and the factor that effect in calcium absorption and pout nursing care plan to repaired any defects such as hypo or hypercalcimia during pregnancy. (Ritchie et al. ,2009).

\section{Aim of The Study}

1- To assess the knowledge, practice and attitude of pregnant women for effect of calcium during pregnancy.

\section{Research Questions}

What's the level of pregnant women knowledge, practice and attitude regarding, calcium and its effect on the pregnancy?

\section{Subjects and Method}

Design: Descriptive design was used in this study.

\section{Settings}

The study was conducted at both in outpatient clinic for pregnant women, in obstetrics and gynecology department at Benha university hospital .

\section{Sample type:}

Systematic random sample. According to admission list

\section{Sample size:}

Based on power analysis equal (300 pregnant women.

\section{Tools of data collection}

Data were collected through the following tools:- 
Tool I: An interviewing questionnaire sheet was done constructed by researcher it includes

\section{Part ( I) -Socio -demographic data:}

It included (name-age -educational level-occupation-socio economic level-level of education.... etc)

\section{Part II obstetric history:-}

It included (number of labor-gestational age in week- number of pregnancy-number of apportion-any congenital anomaliespreterm labor-gravity......etc)

\section{Part (III): knowledge assessment: -}

Include elven questions the following (what is the calcium -source of -important of calcium -signs of calcium increase - signs of calcium decrease -the problem from increase - problem from decrease during pregnancy What is the effect of calcium deficiency on the fetus- What is the impact on the mother calcium deficiency in the future)

Total score: incorrect knowledge $<50 \%$, correct knowledge $>50 \%$

\section{Part (IV): practice assessment: -}

Was reported by women it includes 6 statements about using of calcium and other supplements of calcium.

Scoring system: always done (three score) - done some time (two score)- not done (one score)

\section{- Tool II:}

Modified liker scale to measure the attitude: -
That includes nine statements to assess the important of women to word calcium and their important for your baby and him

\section{Ethical considerations}

- Explanations the purpose of study to all the pregnant women

- Approval of women was obtained before history taken

- After explanation, the purpose of study the pregnant women were assured that the data collected is confident and will be used only for research

- It was explained as follows each study subject is free and the pregnant have the freedom to withdraw from participation in the study at any time.

\section{Data collection procedure:}

- Keeping privacy for all pregnant women during the meeting.

- Explain the purpose from study and data collected from the pregnant women.

- Researcher getting greeting from pregnant women.

- Start to question tool (I) that include.

- Assessment part one (socio demographic data), assess part two (obstetric gynecological data, assess part three (Knowledge assessment) and assessment part four (practice).

- $\quad$ Assessed of the woman attitude tool (II). 
Tahany Sh., Nadia M., Soad A., \& Hemat M.

- The average of women studded where10- 15 pregnant women in the day until the predetermined sample was completed this was repeated

\section{The study limitation:}

-There is the limited number of women refused to participate in the study

-There is the limited number of research that discuses in this topic in Egypt

\section{Administrative design (jury)}

An official permission letter it was obtained from the dean of faculty of nursing to director of Benha university hospital. The title and the objectives of the study explained to them and obtained their cooperation

\section{The validity and reliability:}

The validity of the tool (knowledge, practice, attitude) was reviewed from three experts of maternal and women health nurse for content validity.

The reliability of the toll was assessed.

\section{Statistical Analysis of the study: -}

After completing of data collection, computerized data entry and statistic

Result

\section{Part (1) personnel characteristics}

Table (1): Distribution of personnel characteristics of the studied women

\begin{tabular}{|c|c|c|}
\hline Variable & Frequency & $\%$ \\
\hline \multicolumn{3}{|l|}{ Age in years } \\
\hline $20-$ & 189 & 63.0 \\
\hline 30- & 108 & 36.0 \\
\hline$\geq 40$ & 3 & $\mathbf{1 . 0}$ \\
\hline Mean \pm SD & \multicolumn{2}{|c|}{$28.4867 \pm 4.68647$} \\
\hline \multicolumn{3}{|l|}{ Occupation } \\
\hline Working & 130 & 43.3 \\
\hline House wife & 170 & 56.7 \\
\hline \multicolumn{3}{|c|}{ Educational qualification } \\
\hline University & 111 & 37.0 \\
\hline Secondary & 136 & 45.3 \\
\hline Read and write & 53 & 17.7 \\
\hline \multicolumn{3}{|c|}{$\begin{array}{l}\text { Social standards according to } \\
\text { ( Ministry of Education in Egypt, 2014) }\end{array}$} \\
\hline High standards & 36 & 12.0 \\
\hline Moderate standards & 198 & 66.0 \\
\hline Low standards & 66 & 22.0 \\
\hline
\end{tabular}

Table (1): indicates distribution of personnel characteristics of the studied women, it reveals that $63.0 \%$ of them are in age group from 20 to less than 30 years old, with mean age of $28.4867 \pm 4.68647 .56 .7 \%$ of them are housewives, $45.3 \%$ of them had a secondary education. in addition $66.0 \%$ of them had a moderate level of social standa 
Part (2) Obstetric and Gynecological history

Table (2): Distribution of past obstetric history of the studied women.

\begin{tabular}{|l|c|c|}
\hline Variable & Frequency & $\%$ \\
\hline Numbers of pregnancy & & \\
\hline 1 & 94 & 31.3 \\
\hline 2 & 104 & 34.7 \\
\hline 3 & 102 & 34.0 \\
\hline Times of labor & & \\
\hline Nulli parous & 99 & 33.0 \\
\hline 1 & 128 & 42.7 \\
\hline 2 & 17 & 5.7 \\
\hline 3 & 4 & 1.3 \\
\hline 4 & 52 & 17.3 \\
\hline Times of abortion & & \\
\hline No & 231 & 77.0 \\
\hline 1 & 56 & 18.7 \\
\hline 2 & 11 & 3.7 \\
\hline 3 & 2 & .7 \\
\hline Previous preterm labor & & \\
\hline Yes & 32 & 10.7 \\
\hline No & 268 & 89.3 \\
\hline Previous antepartum & & \\
\hline Yes & 17 & 5.7 \\
\hline No & 283 & 94.3 \\
\hline Previous postpartum & 37 & \\
\hline Yes & 263 & $\mathbf{8 7 . 7}$ \\
\hline No & & \\
\hline & & \\
\hline
\end{tabular}

Table (2): reveals distribution of past obstetric history of the studied women of the studied women, it shows that $34.7 \%$ are gravida (1), $42.7 \%$ of them are para (1), $77.0 \%$ of them had no history of abortion. In addition, $89.3 \%, 94.3 \%, 87.7 \%$, and $81.7 \%$ had no previous history of preterm labor, antepartum heamorrhage, postpartum hemorrhage 
Part (3) knowledge assessment

Table (3): The relation of the studied women total knowledge score and their personnel characteristics.

\begin{tabular}{|c|c|c|c|c|c|c|c|c|}
\hline \multirow[t]{2}{*}{ Variable } & \multicolumn{6}{|c|}{ women total knowledge score } & \multirow{2}{*}{$\begin{array}{ll}\text { Chi } & \text { square } \\
\text { test } & \end{array}$} & \multirow[t]{2}{*}{ P value } \\
\hline & \multicolumn{2}{|c|}{ Poor } & \multicolumn{2}{|c|}{ Average } & \multicolumn{2}{|c|}{ Good } & & \\
\hline Age in years & & & & & & & 3.36 & $>0.05$ \\
\hline 20- & 66 & $62.3 \%$ & 109 & $64.5 \%$ & 14 & $56.0 \%$ & & \\
\hline 30- & 40 & $37.7 \%$ & 57 & $33.7 \%$ & 11 & $44.0 \%$ & & \\
\hline$\geq 40$ & 0 & $0.0 \%$ & 3 & $1.8 \%$ & 0 & $0.0 \%$ & & \\
\hline Occupation & & & & & & & 12.10 & $<0.001 * *$ \\
\hline Working & 37 & $34.9 \%$ & 80 & $47.3 \%$ & 18 & $72.0 \%$ & & \\
\hline House wife & 69 & $65.1 \%$ & 89 & $52.7 \%$ & 7 & $28.0 \%$ & & \\
\hline $\begin{array}{l}\text { Educational } \\
\text { qualification }\end{array}$ & & & & & & & 15.54 & $<0.001 * *$ \\
\hline High & 48 & $45.3 \%$ & 60 & $35.5 \%$ & 3 & $12.0 \%$ & & \\
\hline Moderate & 38 & $35.8 \%$ & 85 & $50.3 \%$ & 13 & $52.0 \%$ & & \\
\hline Low & 20 & $18.9 \%$ & 24 & $14.2 \%$ & 9 & $36.0 \%$ & & \\
\hline $\begin{array}{l}\text { Social } \\
\text { standards }\end{array}$ & & & & & & & 10.20 & $<0.05^{*}$ \\
\hline High & 19 & $17.9 \%$ & 17 & $10.1 \%$ & $\mathbf{0}$ & $0.0 \%$ & & \\
\hline Moderate & 69 & $65.1 \%$ & 113 & $66.9 \%$ & 16 & $64.0 \%$ & & \\
\hline Low & 18 & $17.0 \%$ & 39 & $23.1 \%$ & 9 & $36.0 \%$ & & \\
\hline
\end{tabular}

Table (3): indicates studied women regarding total knowledge score in relation to their personnel characteristics. It was clarified that there was a highly statistical significant relation between their total knowledge score and their occupational status, educational level. In addition, there was a statistical significant relation between their total knowledge score and their social status.

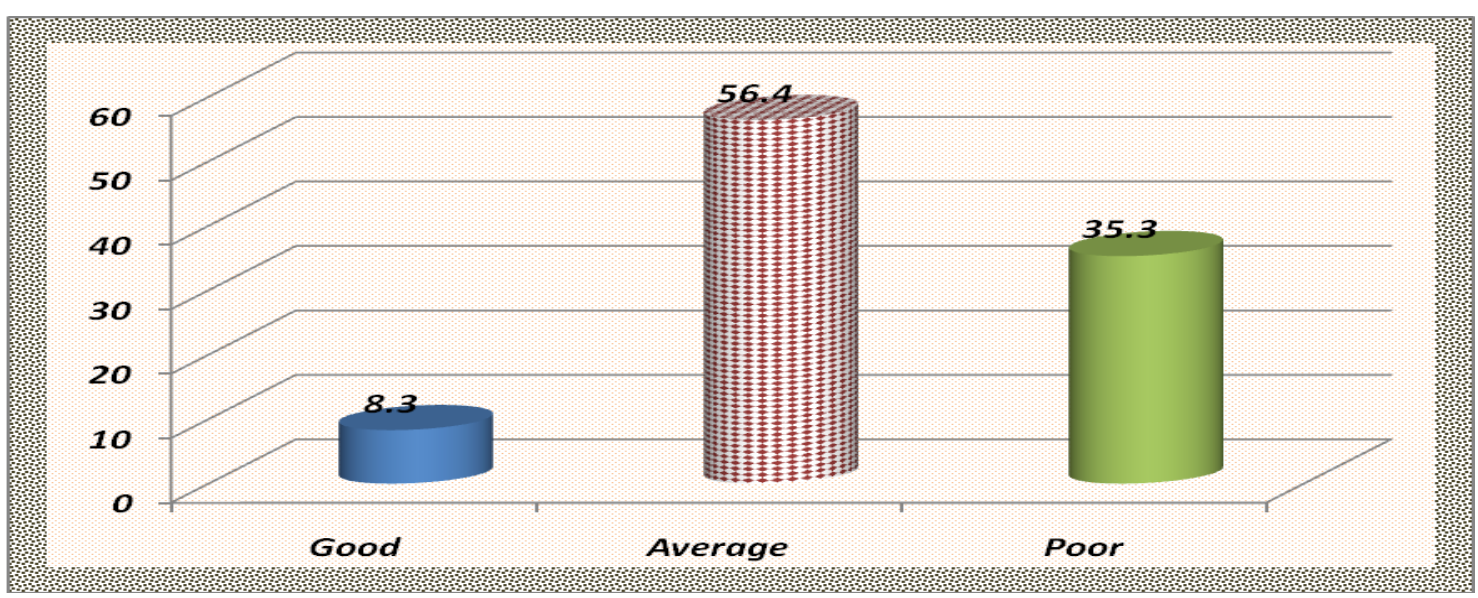

Figure (1): percentage distribution of studied women s' total knowledge score regarding calcium intake. 
Part (4) practice assessment

Table (4): the relation of the studied women total practice score and their personnel characteristics.

\begin{tabular}{|c|c|c|c|c|c|c|}
\hline \multirow[t]{2}{*}{ Variable } & \multicolumn{4}{|c|}{ women total practice score } & \multirow{2}{*}{$\begin{array}{l}\text { Chi } \\
\text { square } \\
\text { test }\end{array}$} & \multirow[b]{2}{*}{$P$ value } \\
\hline & \multicolumn{2}{|c|}{ Unsatisfactory } & \multicolumn{2}{|c|}{ Satisfactory } & & \\
\hline & & & & & \multirow{5}{*}{1.01} & \multirow{5}{*}{$>0.05$} \\
\hline Age nil years & & & & & & \\
\hline $20-$ & 65 & $67.0 \%$ & 124 & $61.1 \%$ & & \\
\hline 30- & 31 & $32.0 \%$ & 77 & $37.9 \%$ & & \\
\hline$\geq \mathbf{4 0}$ & 1 & $1.0 \%$ & 2 & $1.0 \%$ & & \\
\hline \multicolumn{5}{|l|}{ Occupation } & \multirow[t]{3}{*}{0.168} & \multirow[t]{3}{*}{$>0.05$} \\
\hline Working & 42 & $43.3 \%$ & 93 & $45.8 \%$ & & \\
\hline House wife & 55 & $56.7 \%$ & 110 & $54.2 \%$ & & \\
\hline \multicolumn{5}{|l|}{ Educational qualification } & \multirow[t]{4}{*}{0.545} & \multirow[t]{4}{*}{$>0.05$} \\
\hline High & 38 & $39.2 \%$ & 73 & $36.0 \%$ & & \\
\hline Moderate & 41 & $42.3 \%$ & 95 & $46.8 \%$ & & \\
\hline Low & 18 & $18.6 \%$ & 35 & $17.2 \%$ & & \\
\hline \multicolumn{5}{|l|}{ Social standards } & \multirow[t]{4}{*}{1.50} & \multirow[t]{4}{*}{$>0.05$} \\
\hline High & 14 & $14.4 \%$ & 22 & $10.8 \%$ & & \\
\hline Moderate & 65 & $67.0 \%$ & 133 & $65.5 \%$ & & \\
\hline Low & 18 & $18.6 \%$ & 48 & $23.6 \%$ & & \\
\hline
\end{tabular}

Table (4): shows studied women regarding total practice score in relation to their personnel characteristics. It was clarified that there was no statistical significant relation between their total practice score and their occupational status, educational level and social status.

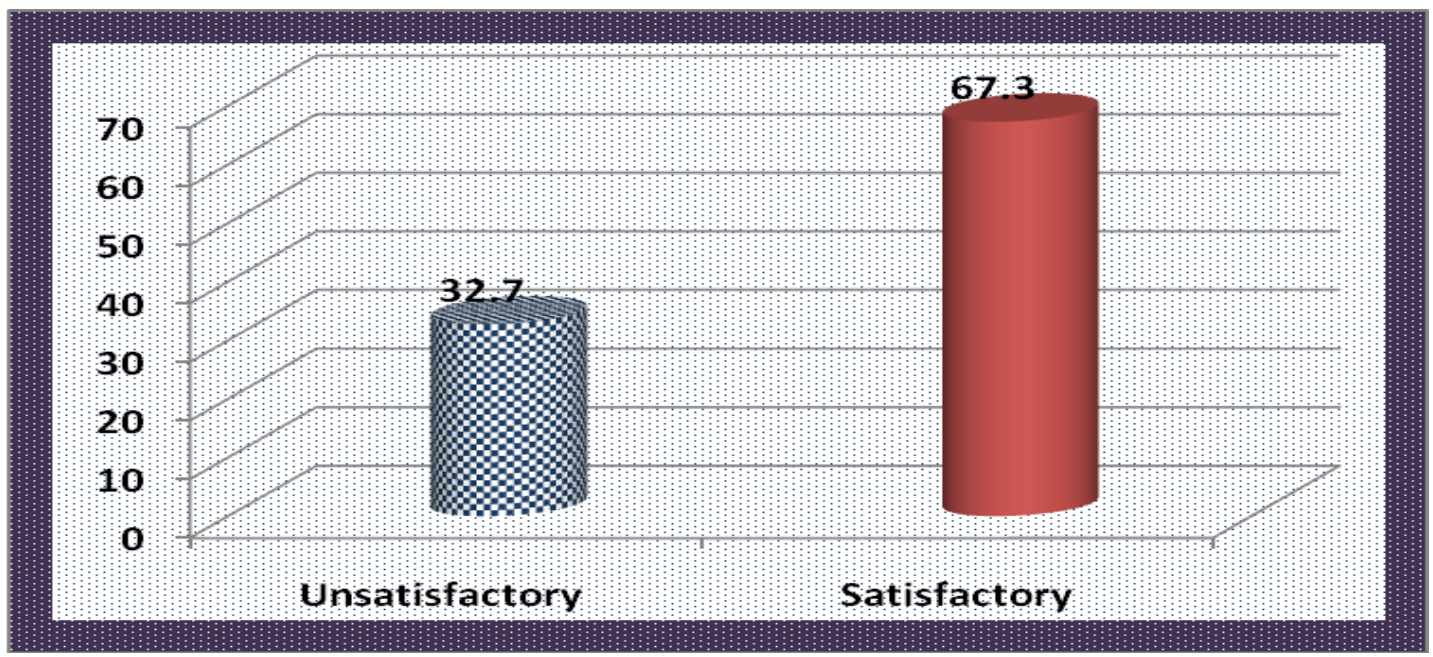

Figure (2): percentage distribution of total practice score of the studied women. 
Tool (II) Assessment of women attitude

Table (5): The relation of the studied women total attitude score and their personnel characteristics.

\begin{tabular}{|c|c|c|c|c|c|c|c|c|}
\hline \multirow[t]{2}{*}{ Variable } & \multicolumn{6}{|c|}{ women total attitude score } & \multirow{2}{*}{$\begin{array}{l}\text { Chi } \\
\text { square } \\
\text { test }\end{array}$} & \multirow[b]{2}{*}{$P$ value } \\
\hline & \multicolumn{2}{|c|}{ Negative } & \multicolumn{2}{|c|}{ To some extent } & \multicolumn{2}{|c|}{ Positive } & & \\
\hline & & & & & & & & \\
\hline & & & & & & & 2.38 & $>0.05$ \\
\hline 20- -2 & 92 & $59.4 \%$ & 69 & $65.7 \%$ & 28 & 70.0\% & & \\
\hline 30- & 61 & $39.4 \%$ & 35 & $33.3 \%$ & 12 & $30.0 \%$ & & \\
\hline$\geq 40$ & 2 & $1.3 \%$ & 1 & $1.0 \%$ & 0 & $0.0 \%$ & & \\
\hline Occupation & & & & & & & 0.839 & $>0.05$ \\
\hline Working & 67 & $43.2 \%$ & 51 & $48.6 \%$ & 17 & $42.5 \%$ & & \\
\hline House wife & 88 & $56.8 \%$ & 54 & $51.4 \%$ & 23 & $57.5 \%$ & & \\
\hline $\begin{array}{l}\text { Educational } \\
\text { qualification }\end{array}$ & & & & & & & 1.89 & $>0.05$ \\
\hline High & 55 & $35.5 \%$ & 43 & $41.0 \%$ & 13 & $32.5 \%$ & & \\
\hline Moderate & 70 & $45.2 \%$ & 45 & $42.9 \%$ & 21 & $52.5 \%$ & & \\
\hline Low & 30 & $19.4 \%$ & 17 & $16.2 \%$ & 6 & $15.0 \%$ & & \\
\hline Social standards & & & & & & & 7.00 & $>0.05$ \\
\hline High & 18 & $11.6 \%$ & 11 & $10.5 \%$ & 7 & $17.5 \%$ & & \\
\hline Moderate & 95 & $61.3 \%$ & 78 & $74.3 \%$ & 25 & $62.5 \%$ & & \\
\hline Low & 42 & $27.1 \%$ & 16 & $15.2 \%$ & 8 & $20.0 \%$ & & \\
\hline
\end{tabular}

Table (5): illustrates studied women regarding total attitude score in relation to their personnel characteristics. It was clarified that there was no statistical significant relation between their total attitude score and their occupational status, educational level and social status.

\section{Table (6): correlation between studied women total knowledge, practice, and attitude score.}

\begin{tabular}{|l|l|l|l|l|l|l|}
\hline \multirow{2}{*}{ Variable } & \multicolumn{2}{l|}{ Total knowledge score } & \multicolumn{2}{l|}{ Total practice score } & \multicolumn{2}{l|}{$\begin{array}{l}\text { Total attitude } \\
\text { score }\end{array}$} \\
\cline { 2 - 8 } & $\mathrm{R}$ & P value & r & P value & r & P value \\
\hline Total knowledge score & $\mathbf{1}$ & & .072 & .214 & $\mathbf{. 0 6 3}$ & .275 \\
\hline Total practice score & .072 & .214 & $\mathbf{1}$ & & $\mathbf{. 0 9 9}$ & $\mathbf{. 0 8 8}$ \\
\hline
\end{tabular}

Table (6): showed correlation between studied women total knowledge, practice, and attitude scores, it was indicated that there was a positive association between studied women total knowledge, practice, and attitude score.

Discussion

Studied women, it was revealed that the mean age of studied women was $28.4867 \pm 4$. 68647.these finding came in the same line with (Arega \& Tachbele ,2015), in the study to assess knowledge, attitudes and practices among pregnant women regarding maternal nutrition among pregnant women, it was revealed that the mean age $( \pm \mathrm{SD})$ of the participants was $28.44( \pm 4.199)$ years.

In addition, the highest percentage of the studied women were housewives and had 
a secondary level of education, these findings are in accordance with (Ahmed et al., 2015), in the study to asses compliance of pregnant women to calcium and iron supplements during pregnancy, it was pointed out that the majority of the study group had a secondary and technical education. The researcher believes that, the knowledge not affect by the level of education but affect by attitude.

The obstetric history that different from woman to other however the number of labor and some disease effect in calcium level in the body. Many problems during pregnancy can be control during anti natal care, if the women don't obtain anti natal care leading to problems for both (mother - fetus). (Ugwu et al., 2014).

Concerning regular attendance of the studied women to antenatal care the present study findings illustrated that the majority of them don't attend regular antenatal care. These findings were contradicting with (Sivapriya \& Parida, 2013), in the study to find out the level of knowledge and practices regarding prevention of anemia among antenatal women, it was indicated that the vast majority of the studied pregnant women had a regular antennal care attendance.

The researcher believes that, the number of pregnancy that affect the level of calcium in the body, the antenatal care it is very important to prevent complication for mother and fetus.

In relation to the obstetric history of the studied women, the present study findings indicated that more than one quarter of they were primigravida. And the vast majority of them didn't have a past obstetric history of preterm labor, ante or post-partum hemorrhage or previous pregnancy induced hypertension. These findings disagreed with (Arega 2015), who pointed out that nearly two third of the studied participants experience a history of abnormal previous pregnancy and delivery.

On the other hand, the present study findings were disagreed with (Ahmed et al.,2015), they added that the majority of the studied subjects had a correct knowledge regarding calcium rich food and calcium supplementation. The researcher believes that, the defect of knowledge result from lake of sources of knowledge such as (Programs, booklets, postersect and health education).

In relation to the knowledge of studied women regarding importance of calcium intake for pregnant women, it was indicated that more than half of them had correct knowledge that calcium intake prevent disease and makes up approximately $2 \%$ total body weight of pregnant women. These finding were supported by (Carroli, 2010), in the study to evaluate "the effects of calcium supplementation on utero-placental and fetoplacental blood flow in low-calcium intake", it was pointed out that recent evidence indicates that calcium supplementation had an effect on uteroplacental blood flow.

In addition (Hofmeyr 2015), indicated that calcium supplementation during the second half of pregnancy reduce blood pressure directly and preventing the endothelial damage, that is associated with pre-eclampsia. The researcher believes that, the knowledge about calcium increase with women that have antenatal care.

Concerning studied women knowledge about the importance of calcium intake for the fetus, the present study findings revealed that the vast majority of studied women had incorrect knowledge regarding importance of calcium to develop a strong heart and overall strong dental and bone growth respectively of the fetus. 
The study result was in agreed with the result from east Wollega that near quarter of respondents had knowledge that decrease calcium intake during pregnancy cause miscarriage or preterm birth. More over, the findings were supported with a study conducted in America at EL-Hospital at which studied women had a lack of awareness regarding effect of inadequate calcium intake during pregnancy on the mother and fetus (Latifa et al., 2012).

The researcher believes that, the knowledge about important calcium for mother that result from appear or sense of sign or symptoms in hair or other person bout the fetus don't watching any signs, lake of health education about calcium.

Studied women knowledge about calcium rich foods, the present study findings illustrated that the vast majority of them had incorrect knowledge regarding salmon and cottage as a rich calcium foods respectively. These finding are in the same line with (Omaset al., 2013) in the study to assess effect of family education for increasing consumption of foods rich with calcium. The researcher believes that, the defect of knowledge result from lake of sources of knowledge .

Concerning studied women total knowledge score in relation to their personnel characteristics. The present study findings indicated that there was a highly statistical significant relation between their total knowledge score and their occupational status, education al level. In addition, there was a statistical significant relation between their total knowledge score and their social status.

These findings are in the same line with a research showed a positive significant relation between knowledge about nutrition, educational level of women and family income and nutritional level of pregnant women (Daba et al., 2015). in addition
(Arega, 2015) illustrated that there was a highly statistical significant difference between studied women knowledge score and their occupational status and educational qualifications. The researcher believes that, found high relationship between family income and nutritional level of pregnant women.

Studied women practice toward calcium intake, the present study findings revealed that only nearly one third of the studied women had a satisfactory practice regarding calcium intake. These findings are in the same line with (Arega,2015) who pointed out that $(34.5 \%)$ of the respondents were found to have good practice regarding mothers' nutrition during their pregnancy.

Women practice toward calcium intake, the present study findings illustrated that the majority of them decrease practice of activity daily, more than half of them of them sometimes intake of calcium supplementation. These findings may be due to insufficient knowledge regarding the importance of daily activity and intake of calcium supplementations. More over these findings may be due to insufficient nutritional counseling that provided to the pregnant women to discuss healthy practice and attitude toward calcium supplementation during pregnancy and its effect on mother and the fetus.

Concerning the relation between studied women total practice score and their personnel characteristics. The present study indicated that there was no statistical significant relation between their total practice score and their occupational status, educational level and social status. These findings are disagreed with (Agueh,2015) in the study to assess" Dietary Calcium Intake and Associated Factors among Pregnant Women in Southern Benin in 2014" it was pointed out that occupation status was associated with adequate calcium. 


\section{Conclusion}

For assessment, the level of pregnant women knowledge found this low level of knowledge about important of calcium for fetus and correct knowledge regarding importance of calcium for mother and have little knowledge about the calcium rich foods, don't have knowledge about the symptoms of calcium disorder

For practice toward calcium intake is poor such as poor dally intake of calcium supplementation, little women exposure to sun light.

For attitude toward calcium intake, the large sample don't know the calcium is essential for diseases prevention and calcium deficiency may cause fetal congenital anomalies respectively.

\section{Recommendation}

In the light of the study findings, the following recommendations are suggested:

1) Health educational should be introduced to the pregnant women about the importance of healthy diet especially calcium and calcium supplementations by health programs.

2) In the future, increase the nutritional health awareness by TV programs as to provide house wives or the all target in the society the proper a correct information, can give excellent results.

All team of nurses educate all women about the important of anti natal care during this visit assessment or follow-up of calcium by observation and ask the women.

\section{References:}

Agueh, V., Tugoué, M., Sossa, C., Métonnou, C. Azandjemè, C., Paraiso, N., Ouendo, M., Ouédraogo, L. and Makoutodé, M. (2015) Dietary Calcium Intake and Associated Factors among Pregnant Women in Southern Benin in 2014. Food and Nutrition Sciences, 6, 945-954. doi: 10.4236/fns.2015.611098.

Ahmed EB, Ali EA, Mohamed EH, Saleh EA, AbdElbaset AK, Mahmmed EM, et al. (2015) Assessment of iron and calcium supplements compliance among pregnant women attending antenatal care unit" of Alsabah Banat primary health care unit in Ismailia, Egypt. J Med Bio Sci Res.;1(3):24-9.

Arega A, tallah ÁN, Duley L. (2015) Calcium supplementation during pregnancy for preventing hypertensive disorders and related problems. Cochrane Database of Systematic Reviews, Issue 3. Art. No.: CD001059. DOI

Carroli G, Merialdi M, Wojdyla D, Abalos E, Campodonico L, Yao SE, et al. (2010) Effects of calcium supplementation onuteroplacental and fetoplacental blood flow in low-calciumintake mothers: a randomized controlled trial. American Journal of Obstetrics and Gynecology; Vol. 202:45. e1-45. e9

Doba G, Beyene F, Fekadu H, Garoma W. (2013) of knowledge of pregnant mothers on maternal nutrition and associated factors. In GutoGidaWoreda, East Wollega Zone, Ethiopia. J Nutr Food Sci.; $3: 235$ 
Gardner, D.G., \&Shoback, D (2012).Green spans basic and clinical endocrinology (8thed). N ewyork:MCGraw Hill, p.300.

Hofmeyr GJ et al. (2012) Calcium supplementation during pregnancy for preventing hypertensive disorders and related problems. Cochrane Database of Systematic Reviews, (8):CD001059.

Kovacs CS, Kronenberg HM. (2013). Maternal-fetal calcium and bonemetabolism during pregnancy, puerperium and lactation. Endocr Rev; 18:832-72. The Endocrine Society; with permission.

Latifa M. Fou.da, Manal H. Ahmed, Shehab NS. (2012) Nutritional Awareness of Women during Pregnancy Journal of American Science .8(7):494-502.

Ministry of Education ( 2014). National strategic plan for education in Egypt: towards a paradigm shift 2013/14 2014/15. Cairo: MoE"

Nix, s. (2014) William's basic nutrition and diet therapy (13 th ed.) St. Louis.Mosby Elsevier, p.126.

Intensive Care Units, MSC, Nursing Faculty, Benha University, Pp: 84-85.

Omas M, Weisman SM. (2013) Calcium supplementation during pregnancy and lactation: effects on the mother and the fetus. Am J ObstetGynecol; 194:937-945

-Sivapriya SM, Parida L. (2015) A study to assess the knowledge and practices regarding prevention of anemia among antenatal women attending a tertiary level hospital in Pune. IJSR NET. 4(3):121014.

Ugwu EO, Olibe AO, Obi SN, Ugwu AO (2014). Determinants of compliance to iron supplementation among pregnant women in Enugu, Southeastern Nigeria. Niger. J. Clin. Pract., 17(5):608-612.

Ritchie LD, Fung EB, Halloran BP,

( 2009).A longitudinal study of calcium homeostasis during human pregnancy and lactation and after resumption of menses. Am J Clin;67:693-701. 06-613.

Villar J, Abdel-Aleem H, Merialdi M, et al. (2010) World Health Organization randomized-trial of calcium supplementation among low calcium intake pregnant women. Am J ObstetGynecol; 194:639-649.

Woodrow JP, Noseworthy CS, Fudge NJ, et al. (2011) Calcitonin/calcitonin generelated peptide protect the maternal skeleton from excessive resorption during lactation [abstract]. Bon Miner Res 18(Suppl- 2): $\quad$ S37. 